\title{
MEDIA SOSIAL MENJERAT MANUSIA DI MASA PANDEMI
}

\author{
Aulia Ramadhina Wiji Utami \\ S1 Psikologi Fakultas Kedokteran Universitas Lambung Mangkurat \\ Email : 2010914120005@mhs.ulm.ac.id
}

\begin{abstract}
Social media has now become people's daily behavior. Starting from the children to the older generation cannot be separated from the existence of social media. The rapid development of technology coupled with the presence of the corona virus pandemic has an impact on all sectors of life, including social life. People, especially in urban areas, have to refrain from going out of the house. The writing of this article discusses how humans can get entangled with social media and the effects of the COVID-19 virus pandemic. The writer uses her personal experience of what she felt during her lifetime in the midst of a viral storm and added from several opinions or theories from the journal references of Lambung Mangkurat University lecturers as review material. The results of this writing show that social media has become a human need to be able to maintain the social, psychological and economic factors of each individual during the corona virus pandemic.
\end{abstract}

\section{Keywords : Social Media, Pandemic, COVID-19}

\section{Abstrak}

Sosial media sekarang sudah menjadi makanan sehari-hari manusia. Mulai dari kalangan anak-anak hingga generasi tua tidak bisa terlepas dari adanya sosial media. Perkembangan teknologi yang semakin pesat ditambah hadirnya pandemi virus corona yang berdampak kepada semua sektor kehidupan termasuk hidup bersosial. Masyarakat khususnya di perkotaan harus menahan diri untuk tidak berpergian keluar rumah. Penulisan artikel ini bertujuan untuk mengetahui bagaimana manusia bisa terjerat dengan sosial media dan pengaruh dari adanya pandemi virus COVID-19. Penulis menggunakan pengalaman pribadinya dari apa yang dirasakan selama masa hidup ditengah badai virus dan ditambahkan dari beberapa pendapat atau teori dari referensi jurnal para dosen Universitas Lambung Mangkurat sebagai bahan peninjauan. Hasil penulisan ini menunjukkan bahwa sosial media telah menjadi kebutuhan manusia untuk bisa tetap mempertahankan faktor sosial, psikologis maupun ekonomi setiap diri individu selama pandemi virus corona.

\section{Kata Kunci : Media Sosial , Masa Pandemi, COVID-19}




\section{Pendahuluan}

Virus Corona merupakan sebuah bencana bagi dunia. Padahal virus ini bukanlah sesuatu yang baru bagi dunia kedokteran. Sejak dahulu peneliti telah mengetahui virus corona berasal dari tubuh kelelawar. Namun, virus corona telah ditemukan berkembang, menyebar dan menyerang pernapasan hingga kekebalan tubuh manusia lebih kuat. Bermula dari Wuhan China, Virus ini kemudian telah merebak dengan cepat keseluruh penjuru dunia. Virus ini dikenalkan dengan nama Novel Coronavirus-2019. Kemudian, penamaan resmi dari WHO tentang infeksi virus yang menimbulkan penyakit ini disebut Coronavirus Disease 19 atau disingkat COVID 19. ${ }^{[1]}$

Indonesia telah merasakan kehadiran virus corona yang menimbulkan dampak begitu besar terhadap makhluk hidup khususnya manusia pada abad ke-21 ini. Sebagai usaha mengurangi dampak penyebaran virus corona, pemerintah mengeluarkan kebijakan social distancing. Hingga menyelenggarakan kebijakan PSBB. Stay at Home and Work from Home. Menurut Oscar, memutus rantai penularan dapat dilakukan dengan melakukan PSBB serta penegakkan lebih ketat terhadap aturan yang berlaku (dalam Dipna, 2020). Namun, pelaksanaan kegiatan ini tak kunjung selesai. Masyarakat menghadapi kekacauan terhadap beberapa sektor kehidupan.

Media sosial merupakan kemajuan teknologi yang saat ini menjadi kebutuhan umat manusia. Menurut Wijayanto (2014), Dalang utama yang aktif menggerakkan perkembangan teknologi informasi komunikasi kebanyakan berasal dari kaum muda, seperti pelajar dan mahasiswa (dalam Rismana dkk, 2016). Namun, tidak hanya remaja, semua kalangan usia pun aktif dengan penggunaan teknologi ini. Manusia giat untuk bermain social media. Layaknya akar pohon yang terus menjerat tubuh manusia untuk terus menggenggam layar elektroniknya. Media sosial sekarang dianggap sangat penting. Pada masa PSBB dikala manusia diharapkan untuk tetap berdiam diri di rumah, hanya sebuah aplikasi elektornik ini saja yang mampu menjadi pelengkap hidup. Tentunya intensitas dari pengunaan media sosial pada masa pandemi menjadi sebuah topik perhatian yang cukup menarik.

Dalam menulis artikel ini, saya sebagai menulis menyadari bahwa menulis merupakan hal yang perlu dilakukan sebagai manusia. Menulis menjadi sebuah bukti bahwa kita telah menyimpan atau menuliskan segala informasi dari segala panca indera yang kita punya dalam otak. Menulis merupakan tanda bahwa otak kita bukan sekedar tong kosong, namun 
memiliki berbagai macam pengetahuan. ${ }^{[2]}$ Menurut Ersis (2015), menulis itu merupakan hal yang mudah. Harus adanya kemauan yang menghasilkan mindset bahwa menulis itu bukan beban. ${ }^{[3]}$ Menulis bisa manusia lakukan dimana saja. Dengan kecanggihan teknologi dan kemudahan yang ada, kita dapat menulis, menggali informasi berupa ilmu maupun pengetahuan apa pun. Secara sadar, adanya pengaruh dari pandemi ini perlu dituangkan, dicermati dan ditelaah. Bagaimana masyarakat menuliskan pandangan mengenai dampak dari corona, khususnya terhadap kehidupan sosial? Penulisan artikel ini menjadi pemenuhan tugas filsafat untuk membuktikan bahwa saya juga bisa men jadi penulis.

\section{Metode}

Metode yang digunakan dalam analisis artikel ini mengunakan metode kajian literatur. Penulis menggunakan beberapa jurnal sebagai sumber penunjang penulisan artikel ini. Terdapat 15 jurnal maupun buku yang menjadi referensi penulisan artikel. 10 jurnal diantaranya merupakan jurnal dari beberapa dosen Universitas Lambung Mangkurat. Peninjauan artikel ini juga didasarkan dari pengalaman pribadi, tentang bagaimana media sosial bisa menjerat manusia di masa pandemi. Dari berbagai sumber yang ada akan menjadi bahan rujukan dari hasil penulisan artikel ini.

\section{Pembahasan}

Media sosial sering juga disingkat penyebutannya menjadi Medsos atau dalam bahasa inggris disebut social media. Menurut KBBI, Media sosial merupakan laman atau aplikasi yang memungkin pengguna dapat membuat dan berbagi isi atau terlibat dalam jaringan sosial. ${ }^{[4]}$ Macam-macam media sosial diantaranya, yaitu:

a. Facebook merupakan media sosial yang diciptakan oleh Mark Zuckerberg

b. WhatsApp merupakan aplikasi pada smartphone untuk berkirim pesan dengan menggunakan internet.

c. Line merupakan media aplikasi chatting yang dikembangkan oleh Line Corporation.

d. Instagram adalah aplikasi sebagai wadah berbagi foto ataupun video.

e. Twitter merupakan sebuah media aplikasi untuk berbagi tulisan yang diciptakan oleh Jack Dorsey.

f. Path merupakan media berbagi foto dan pesan yang dikembangkan oleh Dave Morin dan Shawn.

g. Youtube, merupakan media berbagi video-video unggahan

h. Dan masih banyak lagi 
Dari hasil survei penelitian Andi tentang penggunaan media sosial, sebagian besar dari pengguna internet di Indonesia adalah mahasiswa dan mereka merupakan pengguna aktif media sosial. Kebanyakan dari mahasiswa mengakses media sosial menggunakan smartphone. Dari 99 responden yang ada, mereka tidak hanya menggunakan satu platform medsos. Melainkan beberapa aplikasi. Pada urutan teratas, WhatsApp menjadi media yang paling banyak digunakan dengan capaian 95,96\% responden, dilanjutkan dengan pemakaian Instagram dengan 90,91\% responden, dan pengguna Youtube dengan $73,74 \%$ responden. Kemudian disusul dengan pengguna Facebook dan Line. (Andi, 2019)

Berdasarkan pemanfaatannya menurut Whiting \& Williams (2013), terdapat tujuh kategori alasan menggunakan media sosial, yaitu: (1) sebagai alat komunikasi; (2) untuk wadah mencari informasi; (3) sebagai interaksi sosial; (4) sebagai hiburan atau relaksasi melalui tontonan video maupun musik; (5) pengisi waktu luang; (6) sebagai pengisi waktu kosong; (7) bisnis online.(dalam Andi, 2019)

Dari hasil penelitian lain, menunjukkan bentuk aktualisasi diri pada remaja adalah dengan pengunaan media sosial path, artinya tingginya tingkat intensitas pengunaan media sosial (khususnya Path dalam penelitian ini) dikarenakan adanya aktualisasi diri pada remaja. (Putri dkk, 2020) $)^{[5]}$

Berdasarkan hasil penelitian diatas, kita mengetahui bahwa adanya kemauan seorang individu mengerahkan segala kemampuannya agar dapat memenuhi keinginannya adalah dengan melalui medsos. Pada masa pandemi seperti ini, kebutuhan yang paling mendasar seseorang adalah melakukan hubungan sosial, berkomunikasi. Adanya medsos sangat membantu setiap individu dikala kebijakan pemerintah seperti PSBB menjadi penghalang setiap manusia untuk menjalin interaksi secara langsung. Media Sosial menghadirkan fitur chat dan call agar kita masih terus terkoneksi dengan orang lain. Media sosial juga menjadi sebuah tempat bertukarnya informasi. Hasil Penelitian dari pada 50 orang sample acak di instagram menunjukkan $80 \%$ orang menyetujui bahwa media sosial dapat digunakan sebagai media informasi dan $93 \%$ orang setuju dengan media sosial sebagai media informasi COVID-19. (Rohmah, 2020)

Dari hasil penelitian Desi (2020), menunjukkan bahwa penggunaan media sosial instagram dalam penyiaran pesan dakwah cukup efektif sebagai sumber 
informasi materi dan pesan-pesan dakwah mengenai akhlak dan sebagainya. ${ }^{[10]}$

Apalagi menyangkut tentang pendidikan. Tenaga pendidik mulai memperhatikan teknologi dimasa stay at home untuk tetap melakukan sistem pembelajaran K13. Pembelajaran dengan Kurikulum 2013, yaitu pembiasaan membangun pengetahuan peserta didik secara mandiri berdasarkan proses aktivitas dari beberapa sumber (Syaharuddin dan Mutiani, 2020). Media Sosial seperti Youtube dan WhatsApp inilah menjadi ladang sumber ilmu pengetahuan. Pembelajaran semua lewat daring. Tugas maupun ujiannya pun melalui layar kaca. Medsos yang dulu dianggap sebagai sumber masalah belajar. Sekarang menjadi wadah kebutuhan murid memperoleh ilmu dari guru.

Media sosial menjadi sangat dibutuhkan. Ia menjadi wadah untuk memperbaiki dan menguras keadaan ekonomi. Pada masa pandemi, penjual usaha tidak bisa lagi menunjukkan dagangannya secara langsung karena adanya kebijakan stay at home. Agar ia tetap bisa mempromosikannya hadirlah medsos sebagai marketplace. Semua produk jualan dapat dilihat melalui online dan dibuat sesuai pesanan. Kebutuhan terpenuhi dengan cepat tanpa perlu keluar rumah. Namun, kemudahan ini juga membuat dompet terkuras lebih cepat. Kemudahan transaksi dan harga promo membuat manusia berlaku konsumtif. Keinginan untuk memuaskan nafsu lebih tinggi.

Keadaan Psikologis pun menjadi alasan sosmed di era COVID 19 ini diperlukan. Menurut penelitian Rohmah (2020), 80\% responder setuju bahwa media sosial bisa menjadi pelarian diri dari segala aktifitas dan masalah. Ia menjadi pemuas individu, menghibur keadaan psikologisnya yang merasakan bosan, sedirian di kala pandemi Covid. Sendiri dan merasa sepi ini berbahaya karena Orang yang merasa kesepian berisiko terkena stress psikis yang membuat dirinya tertekan. (Anindya,2020)

Dalam survei yang dilakukan I Gede, bahwa kebanyakan dari respondennya yang merupakan siswa SMP menggunakan media sosial dalam kurun waktu 3-4 jam.(Gede, 2020). Sedangkan diketahui dalam survei bahwa responden mahasiswa setiap hari mengakses media sosial selama 1-6 jam. (Andi,2019). Rata-rata aktivitas penikmat medsos dilakukan pada malam hari. Aktivitas penggunaan media sosial ini cenderung tinggi dan bisa berakibat buruk. Menurut penelitian Isti dan Alfred (2020), Penggunaan media sosial dengan aktivitas tinggi $3 \mathrm{x}$ lipat berisiko 
mengalami gangguan depresi dan $4 x$ lipat berisiko mengalami gangguan kecemasan ${ }^{[1]}$

Media sosial ternyata semakin berbahaya karena ia merupakan wadah untuk mengekpresikan kebebasan. Kebiasaan menulis menjadikannya sebagai sesuatu yang mengasyikkan. Ia akan sangat mudah menulis. ${ }^{[7]}$ Postingan tulisan individu ternyata tidak hanya sesuatu yang baik, namun juga pendapat sarkasme maupun kesedihan. Dimasa stay at home tidak ada yang bisa mengatur ketikan masing-masing individu. Tulisan atau cuitan orang tertentu di media sosial yang mengadu-domba atau memaki-maki. Kemampuan mengadu dombanya semakin bagus. Karena ia menyempurnakan tekniknya. Menulis melatih diri kita untuk bisa terus berkembang. ${ }^{8]}$ Namun akan lebih baik mengganti kalimat atau membuang kata, misalnya bila tidak senonoh. Menfilter itu adalah sebuah keharusan dimana kita memperbaiki yang perlu diperbaiki ${ }^{[9]}$ Diskusikan sebuah pendapat pemikiran kita semasa hidup dengan hal yang positif. ${ }^{[]}$Pada masa pandemi sering sekali muncul ujaran atapun berita hoaks yang beredar. Manusia berlomba-lomba mengkoarkan informasi terbaru agar bisa tetap eksis dalam kehidupan (setidaknya dalam dunia maya). Mereka ingin diakui keberadaannya. Dengan media sosial lah mereka tetap aman. Namun, inilah yang menyebabkan manusia era 4.0 terjerat dengan media sosial.

\section{Simpulan}

Berdasarkan hasil penelitian, menunjukkan bahwa media sosial telah menjadi kebutuhan manusia untuk bisa tetap mempertahankan faktor sosial agar bisa saling terhubung untuk melakukan komunikasi, faktor psikologis sebagai pemuasan diri dari kehidupannya yang dirasa membosankan serta faktor ekonomi dimana manusia tidak bisa lepas dari transaksi jual beli untuk memenuhi kebutuhan setiap diri individu selama pandemi virus corona. Hal ini juga dilihat berdasarkan intensitas tinggi penggunaan media sosial. Tanpa adanya media sosial, sulit untuk memperoleh informasi dan menjaga eksistensi diri sendiri.

\section{Referensi atau Daftar Pustaka}

${ }^{[1]}$ Anindya, I. \& Tomhisa, A, R., (2020). Risiko Gejala Somatik Pada Pengguna Media Sosial Yang Terpapar Informasi Seputar Covid19 dalam COVID-19 DALAM RAGAM TINJAUAN PERSPEKTIF. Depok: Mbrige Press.

Videlia, Dipna. Arti PSBB yang Dibuat Untuk Cegah Penyebaran Corona 
di Indonesia, 13 April 2020, https://www.google.com/amp/s/am p.tirto.id/arti-psbb-yang-dibuatuntuk-cegah-penyebaran-coronadi-indonesia-eMXT. Diakses 2 Desember 2020

Rismana, A., Normelani, E., \& Adyatma, S. (2016). Pengaruh Jejaring Sosial Terhadap Motivasi Belajar SiswaSiswi Sekolah Menengah Pertama (SMP) Di Kecamatan Banjarmasin Barat

[2] Abbas, Ersis Warmansyah. (2020). Menulis Di Otak Dan Menuliskan Tulisan Di Otak.

[3] Abbas, Ersis Warmansyah. (2015). Menulis Membangun Mindset. Bandung: Wahana Jaya Abadi

Abbas, Ersis Warmansyah. (2020). Menulis di Era Covid-19: Memanage Trauma Psikologis Menghindari Psikosomatis

${ }^{[4]}$ Daring, K.(2016). KBBI Daring. Diakses pada 2 Desember 2020

Saputra, Andi.(2019). Survei Penggunaan $\begin{array}{lrr}\text { Media Sosial } & \text { Di } & \text { Kalangan } \\ \text { Mahasiswa } & \text { Kota } & \text { Padang } \\ \text { Menggunakan } & \text { Teori } & \text { Uses and } \\ \text { Gratifications } & & \\ \end{array}$
${ }^{[5]}$ Putri, R., A, Erlyani, N., \& Marina DW. (2020). Hubungan Antara Aktualisasi Diri Dengan Intensitas Pengunaan Media Sosial Path pada remaja di Sekolah Menengah Atas Negeri 2 Banjarbaru.

Rohmah, N,N., (2020). Media Sosial Sebagai Media Alternatif Manfaat dan Pemuas Kebutuhan Informasi Masa Pandemik Global Covid 19 (Kajian Analisis Teori Uses And Gratification)

${ }^{[6]}$ Anggraini, D.(2020). EFEKTIVITAS MEDIA SOSIAL INSTAGRAM DALAM PENYAMPAIAN PESAN DAKWAH (Studi Pada Akun_Instagram@ islamdakwahcom)(Doctoral dissertation, UIN Raden Intan Lampung).

Syaharuddin, S., \& Mutiani, M. (2020). STRATEGI PEMBELAJARAN IPS: Konsep dan Aplikasi

${ }^{[7]}$ Abbas, Ersis Warmansyah. (2015). Menulis Mengasyikkan. Bandung: Wahana Jaya Abadi

${ }^{[8]}$ Abbas, Ersis Warmansyah. (2015). Menulis Menuliskan Diri. Bandung: Wahana Jaya Abadi. 
${ }^{[9]}$ Abbas, Ersis Warmansyah. (2008),

Menulis dengan Gembira. Yogya:

Gama Media.

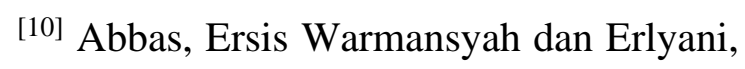

Neka. (2020). Menulis Di Kala

Badai COVID-19 